\title{
TEMPORAL FIXATION IN AMBLYOPIA
}

\author{
BY \\ W. E. GILLIES \\ Melbourne, Australia
}

IN the course of examining 332 cases of amblyopia for eccentric fixation, a particular group of cases was noticed, which was distinguished by fixation temporal to the fovea. There was usually a history of previous operation or occlusion or both, and treatment of the amblyopia rarely resulted in any improvement of vision. Temporal fixation has previously been recognized in cases of strabismus and amblyopia (Cüppers, 1962) but this group of cases is presented because of their special features and clinical findings, which may suggest a mechanism producing the condition.

In considering these cases, "eccentric fixation" was taken to be that condition in which an eccentric point of the retina replaces the fovea as the point on which the principal visual direction is centred. It occurs mainly in cases of amblyopia associated with convergent squint, and the fixation point is usually nasal to the fovea, possibly because it arises as a result of abnormal retinal correspondence.

Eccentric fixation may also occur in amblyopia secondary to anisometropia, with or without a small degree of convergent squint. Again it is usually nasal in direction. Some of these cases may exhibit a considerable amplitude of fusion and occasionally even weak stereopsis. The patient may appear to have normal retinal correspondence to some tests, but many have small degrees of abnormal retinal correspondence and fixation disparity (Arruga and Downey, 1960).

The degree of eccentricity in anisometropic amblyopia tends to be small, e.g. 2-3 but it does appear to be a genuine eccentric fixation.

"Eccentric viewing" in this series was considered to be that condition in which the fovea remains the point on which the principal visual direction of the eye is centred, but in which because of a central scotoma the fixation of small objects may be displaced from the centre so that it is sited around the borders of this scotoma. This eccentricity may be variable in location, changing from the nasal to the temporal side of the scotoma, or it may be fairly constant around one point on the margin of the scotoma. If in time fixation becomes located on or near one point, true eccentric fixation may develop, provided the principal visual direction also becomes located on this point. This may be the mechanism whereby eccentric fixation is produced in anisometropic amblyopes with little or no squint, and it is likely that such a mechanism is involved in causing fixation temporal to the fovea in the cases under consideration. It may sometimes be difficult to decide whether true eccentric fixation is present, or whether the condition is one of eccentric viewing (von Noorden and Mackensen, 1962; Arruga, 1962). 


\section{Clinical Material}

41 patients with fixation temporal to the fovea were detected in the course of examining and treating 332 cases of amblyopia with a visual acuity less than 6/18 (all) in the amblyopic eye.

32 of these patients presented with fixation temporal to the fovea and in the other nine the temporal fixation arose during treatment.

The 32 patients presenting with temporal fixation were divided into four groups:

I. Convergent squint with no significant vertical deviation (12 patients compared with 146 in the whole series).

II. Convergent squint with a well marked or predominant vertical deviation (16 patients compared with 129 in the whole series).

III. Anisometropia with no squint or only a convergent squint of only $10^{\circ}$ or less ( 3 patients compared with 46 in the whole series).

IV. Divergent squint (1 patient compared with 11 in the whole series).

The chief clinical features are set out in the Table (opposite).

\section{Observations}

(1) Almost all patients in all three groups had had 6 months, or more occlusion of the sound eye and many had had surgical treatment as well.

In three patients, one in each of the first three groups, there had been neither occlusion nor operation.

(2) Visual acuities ranged from $6 / 36$ to $6 / 60$ and 2/60. About one-third of the patients had $6 / 36$ vision, one-third $6 / 60$ vision, and one-third less than $6 / 60$, with a similar distribution in the three main groups.

(3) Eleven patients showed evidence of abnormal retinal correspondence in the direction of the convergent squint. This was usually elicited on the synoptophore, after much stimulation to overcome dense suppression, the diagnosis being made on the basis of a "crossing" angle less convergent than the objective angle. The other cases usually showed dense suppression-especially in the second group.

(4) Eleven patients in whom visual field examination was carried out had a small central relative scotoma. Fixation tended to be to the temporal side of this.

(5) In eleven patients in whom the visual acuity was tested, the lines and letters on a Snellen's chart appeared clearer on the nasal side than on the temporal side.

(6) All but two patients fixed $2-3^{\circ}$ temporal to the fovea. The other two fixed 4-6 $6^{\circ}$ temporal.

\section{Response to Treatment}

Group I. Out of twelve patients six had treatment.

There was moderate improvement in two: the visual acuity improved from $2 / 60$ to $6 / 18$ in one and from $6 / 60$ to $6 / 18$ in the other.

Slight improvement took place in two patients: $6 / 60$ to $6 / 36$ and $6 / 36$ to $6 / 24$.

In all four fixation became central.

Two patients did not improve with treatment.

Of the patients having treatment the best results were obtained in those aged 7 years or less with occlusion of the amblyopic eye for 3 months or more, followed by occlusion of the sound eye. Pleoptic treatment was not rewarding in these patients. 
TABLE

TEMPORAL FIXATION IN AMBLYOPIA

\begin{tabular}{|c|c|c|c|c|c|c|c|c|c|}
\hline Group & $\begin{array}{c}\text { Age } \\
\text { (yrs) }\end{array}$ & $\begin{array}{l}\text { Visual } \\
\text { Acuity }\end{array}$ & $\begin{array}{c}\text { Nasal } \\
\text { Blurring }\end{array}$ & $\begin{array}{l}\text { Central } \\
\text { Scotoma }\end{array}$ & $\begin{array}{l}\text { Binocular } \\
\text { Function }\end{array}$ & $\begin{array}{c}\text { Previous } \\
\text { Occlusion } \\
\text { (mths) }\end{array}$ & $\begin{array}{l}\text { Previous } \\
\text { Surgery }\end{array}$ & $\begin{array}{c}\text { Degrees } \\
\text { of } \\
\text { Deviation }\end{array}$ & $\begin{array}{l}\text { Degree of } \\
\text { Eccentric } \\
\text { Fixation }\end{array}$ \\
\hline I & $\begin{array}{r}12 \\
9 \\
13 \\
20 \\
5 \\
9 \\
10 \\
4 \\
9 \\
9 \\
8 \\
13\end{array}$ & $\begin{array}{l}3 / 60 \\
2 / 60 \\
6 / 36 \\
2 / 60 \\
6 / 36 \\
2 / 60 \\
6 / 60 \\
6 / 60 \\
6 / 60 \\
6 / 36 \\
4 / 60 \\
6 / 36\end{array}$ & $\begin{array}{l}- \\
- \\
\overline{Y e s} \\
\overline{\text { Yes }} \\
\text { Yes } \\
\overline{\text { Yes }} \\
\text { Yes } \\
\text { Yes } \\
-\end{array}$ & $\begin{array}{l}- \\
- \\
\text { Yes } \\
\text { Yes } \\
\overline{\text { Yes }} \\
\text { Yes } \\
\overline{\text { Yes }} \\
\overline{\overline{Y e s}}\end{array}$ & $\begin{array}{l}\text { Suppres- } \\
\text { sion } \\
\text { Suppres- } \\
\text { sion } \\
\text { ARC } \\
\text { ARC } \\
\text { ARC } \\
\text { ARC } \\
\text { ARC } \\
\text { ARC } \\
\text { ARC }\end{array}$ & $\begin{array}{c}9 \\
6-8 \\
18 \\
\mathrm{Nil} \\
6 \\
1-2 \\
12 \\
6 \\
36 \\
1 \frac{1}{2} \\
7-9 \\
24\end{array}$ & $\begin{array}{l}\text { Yes } \\
\text { Yes } \\
= \\
\overline{\overline{Y e s}} \\
\text { Yes } \\
\overline{\text { Yes }} \\
\overline{\text { Yes }} \\
-\end{array}$ & $\begin{array}{l}20^{\circ} \rightarrow 12^{\circ} \\
32^{\circ} \rightarrow 20^{\circ} \\
20^{\circ} \\
20^{\circ} \\
20^{\circ} \\
35^{\circ}-45^{\circ} \rightarrow \\
\text { parallel } \\
40^{\circ} \rightarrow 4^{\circ} \\
20^{\circ}-30^{\circ} \\
40^{\circ} \rightarrow 20^{\circ} \\
15^{\circ}-25^{\circ} \\
40^{\circ} \rightarrow 20^{\circ} \\
30^{\circ}\end{array}$ & $\begin{array}{l}2-3^{\circ} \mathrm{T} \\
2^{\circ} \mathrm{T} \\
2^{\circ} \mathrm{T} \\
3^{\circ} \mathrm{T} \\
3^{\circ} \mathrm{T} \\
3^{\circ} \mathrm{T} \\
3^{\circ} \mathrm{T} \\
2-3^{\circ} \mathrm{T} \\
3^{\circ} \mathrm{T} \\
3^{\circ} \mathrm{T} \\
4-6^{\circ} \mathrm{T} \\
3^{\circ} \mathrm{T}\end{array}$ \\
\hline II & $\begin{array}{r}5 \\
7 \\
9 \\
9 \\
10 \\
12 \\
6 \\
9 \\
8 \\
7 \\
3 \\
15 \\
10 \\
7 \\
8 \\
7 \\
11\end{array}$ & $\begin{array}{l}3 / 60 \\
6 / 60 \\
6 / 60 \\
6 / 60 \\
6 / 60 \\
6 / 36 \\
4 / 60 \\
6 / 36 \\
6 / 60 \\
\overline{2} / 60 \\
6 / 36 \\
3 / 60 \\
5 / 60 \\
6 / 60 \\
6 / 60\end{array}$ & $\begin{array}{l}\overline{\text { Yes }} \\
- \\
- \\
- \\
- \\
\text { Yes } \\
= \\
\overline{\text { Yes }} \\
\text { Yes } \\
= \\
- \\
-\end{array}$ & $\begin{array}{l}- \\
- \\
- \\
- \\
- \\
\text { Yes } \\
- \\
\bar{Y} \\
\text { Yes } \\
= \\
- \\
-\end{array}$ & $\begin{array}{c}- \\
- \\
\text { Suppres- } \\
\text { sion } \\
\text { Suppres- } \\
\text { sion } \\
\text { Suppres- } \\
\text { sion } \\
\text { Suppres- } \\
\text { sion } \\
\text { ARC } \\
\text { Suppres- } \\
\text { sion } \\
\text { Suppres- } \\
\text { sion } \\
\text { ARC } \\
\text { ARC } \\
- \\
- \\
-\end{array}$ & $\begin{array}{c}12 \\
10 \\
6 \\
6 \\
6 \\
15 \\
2 \\
15 \\
24 \\
9 \\
8 \\
2 \\
\text { Nil } \\
2 \\
9 \\
30\end{array}$ & $\begin{array}{c}\text { Yes } \\
\text { Yes } \\
\text { Yes } \\
\text { Yes } \\
- \\
- \\
\text { Yes } \\
\text { Yes } \\
\text { Yes } \\
\text { Yes } \\
\text { Yes } \\
\text { Yes } \\
\text { Yes } \\
\text { Yes } \\
-\end{array}$ & $\begin{array}{l}45^{\circ} \rightarrow 10^{\circ} \\
25^{\circ} \rightarrow \\
\text { parallel } \\
30^{\circ} \rightarrow 4^{\circ} \\
35^{\circ} \rightarrow 3^{\circ} \\
20^{\circ} \mathrm{L} / 8 \\
40^{\circ} \\
\rightarrow 3^{\circ} \\
40^{\circ} \rightarrow 20^{\circ} \\
30^{\circ} \rightarrow \\
\text { parallel } \\
35^{\circ} \rightarrow 20^{\circ} \\
40^{\circ} \rightarrow 10^{\circ} \\
35^{\circ} \\
10^{\circ} \\
\rightarrow 15^{\circ} \\
\text { Slight } \\
\text { LDS } \\
7^{\circ} \\
\text { L10 + + }\end{array}$ & $\begin{array}{l}3-4^{\circ} \mathrm{T} \\
3^{\circ} \mathrm{T} \\
2-3^{\circ} \mathrm{T} \\
3^{\circ} \mathrm{T} \\
3^{\circ} \mathrm{T} \\
1-2^{\circ} \mathrm{T} \\
1-2^{\circ} \mathrm{T} \\
1-2^{\circ} \mathrm{T} \\
5-6^{\circ} \mathrm{T} \\
3-4^{\circ} \mathrm{T} \\
3-4^{\circ} \mathrm{T} \\
2-3^{\circ} \mathrm{T} \\
2-3^{\circ} \mathrm{T} \\
1-2^{\circ} \mathrm{T} \\
2-3^{\circ} \mathrm{T} \\
2^{\circ} \mathrm{T}\end{array}$ \\
\hline III & $\begin{array}{r}10 \\
9 \\
14 \\
\end{array}$ & $\begin{array}{l}3 / 60 \\
6 / 36 \\
6 / 36\end{array}$ & $\begin{array}{l}- \\
\text { Yes }\end{array}$ & $\begin{array}{l}\overline{\text { Yes }} \\
\text { Yes }\end{array}$ & $\begin{array}{l}\underset{\mathrm{ARC}}{\mathrm{ARC}} \\
\mathrm{ARC}\end{array}$ & $\begin{array}{r}12 \\
9 \\
\mathrm{Nil}\end{array}$ & $\begin{array}{l}- \\
-\end{array}$ & $\begin{array}{r}5^{\circ} \\
10^{\circ} \\
10^{\circ}\end{array}$ & $\begin{array}{l}2^{\circ} \mathrm{T} \\
2-3^{\circ} \mathrm{T} \\
2-3^{\circ} \mathrm{T}\end{array}$ \\
\hline IV & 7 & $6 / 36$ & - & - & ? Fusion & 5 & - & $-20^{\circ}-0^{\circ}$ & $2^{\circ} \mathrm{T}$ \\
\hline
\end{tabular}

$\left(30-45^{\circ}\right.$ denotes variable angle. $40^{\circ} \rightarrow 20^{\circ}$ denotes pre- and post-operative angles)

$$
\begin{array}{ll}
\text { ARC } & =\text { Abnormal retinal correspondence. } \\
\text { NRC } & =\text { Normal retinal correspondence. } \\
\text { LDS } & =\text { Left divergent squint } \\
\text { L10 }++ & =\text { Strong overaction of left inferior oblique muscle } \\
\text { T } & =\text { Temporal to central fovea }
\end{array}
$$

One patient was given no treatment, and five are awaiting or still undergoing treatment. 
All these patients had previously had 6 months' or more occlusion, except the one who failed to improve.

Group II. Seven patients were treated and none was improved. Five were treated with pleoptics and two with occlusion of the amblyopic eye. All were aged from 7 to 13 years.

Group III. Two patients were treated. One achieved a moderate improvement with pleoptics, the visual acuity improving from $3 / 60$ to $6 / 24$, and fixation becoming central. The other failed to improve with pleoptic treatment.

In all groups fifteen patients were treated, of whom three achieved a moderate improvement, two a slight improvement, and ten were not improved with treatment.

\section{Discussion}

It is of interest to consider the mechanism by which temporal fixation arises in amblyopia.

Pugh (1962) has pointed out that in amblyopia associated with convergent squint grouped letters arranged in a line appear to be clearer at one end of a line and blurred at the other end. Individual letters appeared blurred to one side. This blurring and distortion takes place in a constant direction. This appearance may arise from abnormal retinal correspondence causing a disturbance of the spatial values of the retinal elements between the fovea and the retinal point nasal to it corresponding with the fovea of the opposite eye. Because of this an object is seen more clearly if the image falls on the retinal area temporal to a central foveal scotoma, than if it falls on a retinal area nasal to a central foveal scotoma.

It is possible that temporal fixation may arise in a convergent squint when a preexisting nasal eccentric fixation is broken down by prolonged occlusion of the sound eye, particularly if this is accompanied by operation. Foveal inhibition persists in some cases and the spatial values of the retina nasal to the fovea remain disordered. Consequently, it may be expected that the retina temporal to the fovea which is relatively free from inhibition and the receptors of which retain more normal spatial values may be chosen for fixation.

(1) Temporal blurring of grouped letters was present in all of the eleven patients examined for this, i.e. blurring corresponding to the original shift in retinal receptor values and not in the direction of the temporal fixation.

(2) Evidence of abnormal retinal correspondence was present in eleven patients, and this was always nasal in direction, i.e. in the direction due to the convergent squint.

(3) A small central scotoma was present in the eleven patients tested, and in some of these fixation was located towards the temporal side of the scotoma.

(4) Among the patients in whom temporal eccentric fixation arose during treatment, four originally fixed in the region of the optic disc and one fixed about $5^{\circ}$ nasally between the fovea and the disc. Four appeared to be eccentric viewers with convergent squint; two of these èccentric viewers showed abnormal retinal correspondence, and two showed deep suppression.

In most patients with temporal fixation the degree of eccentricity is small. If the eccentricity is large another mechanism may be involved. 
In a few patients temporal fixation may arise without occlusion or operation.

The results of pleoptic treatment in patients with temporal fixation were poor, and occlusion, whether of the amblyopic eye or the sound eye, was disappointing. Since temporal fixation appears to occur mainly in patients who have had prolonged occlusion or operation or both, it seems important to establish the state of the fixation in all amblyopic patients, and to treat the eccentricity effectively before proceeding with further occlusion and surgery. This should be done at an early age, for temporal fixation and all types of eccentric fixation appear to respond better if they are diagnosed and treated early.

Whether temporal fixation represents a specialized form of eccentric viewing or a true form of eccentric fixation may sometimes be difficult to decide. Indeed the former, if present for a long period, probably becomes established as true eccentric fixation.

\section{Summary}

(1) The clinical features and results of treatment of 41 amblyopic patients with temporal eccentric fixation are described; 32 of them presented with temporal fixation, and in the other nine the temporal fixation arose during treatment.

(2) This condition was associated with considerable visual impairment.

(3) The majority of cases presenting with temporal fixation had had previous operation, or prolonged occlusion of the sound eye, or both.

(4) In patients in whom the condition arose during treatment there was pre-existing nasal eccentric fixation or eccentric viewing.

(5) The results of all forms of treatment of this group of cases were poor, only three of fifteen patients treated attaining a moderate degree of improvement.

(6) A mechanism by which this condition may arise from abnormal retinal correspondence or pre-existing eccentric fixation is suggested.

(7) The state of the fixation should be checked before commencing treatment in all cases of amblyopia or squint. This should be done at as early an age as possible.

My thanks are due to Miss A. Syme and Miss V. Blaubaum for their invaluable help with these patients, and also to the surgeons at the Royal Victorian Eye and Ear Hospital who freely referred them.

The work carried out was financed in part by a grant under Research Project 14 of the Royal Victorian Eye and Ear Hospital.

\section{REFERENCES}

Arruga, A. (1962). Trans. ophthal. Soc. U.K., 82, 45.

and DowNEY, R. (1960). Brit. J. Ophthal., 44, 492.

CÜPPERS, C. (1962). Trans. ophthal. Soc. U.K., 82, 3.

PuGH, M. (1962). Brit. J. Ophthal., 46, 193.

von NOORDEN, G. K., and MACKENSEN, G. (1962). Amer. J. Ophthal., 53, 642. 